\title{
PEWARISAN HAK ATAS TANAH DALAM PERKAWINAN ANTAR NEGARA
}

\author{
Taufika Hidayati ${ }^{1}$, Yusuf Hanafi Pasaribu ${ }^{2}$ \\ ${ }^{1}$ Universitas Pembinaan Masyarakat Indonesia, Indonesia \\ ${ }^{2}$ Universitas Pembinaan Masyarakat Indonesia, Indonesia \\ *Correspondence:taufikahidayati30@gmail.com
}

Received: 25 Juli 2021; Accepted: 30 September 2021; Published: 30 September 2021

\begin{abstract}
The phenomenon of inter-state marriage in Indonesia has an influence on legal actions in it, especially the issue of children born and having dual citizenship after Law Number 12 of 2006 concerning Citizenship was passed by the Government. This study aims to measure the extent to which children born from these marriages get inheritance rights with underage positions. In addition, what is the legal status based on Law Number 1 of 1974 concerning Marriage and Law Number 5 of 1960 concerning Land regarding the position of land inheritance rights. This study uses an empirical normative method, which combines legal research methods that not only view law as a prescriptive (determining) and applied scientific discipline, but also descriptive (explaining) based on the reality of legal developments in society. The results of this study indicate that children born from inter-state marriages who have dual citizenship and are still minors are entitled to land inheritance rights in the form of property rights provided that the child must choose Indonesian citizenship at the age of 18 (eighteen) years based on the laws and regulations. valid invitation.
\end{abstract}

Keywords: inheritance; international marriage; dual nationality

\begin{abstract}
Abstrak
Fenomena perkawinan antar negara di Indonesia memberi pengaruh dalam perbuatan hukum di dalamnya, terutama persoalan anak yang lahir dan memiliki kewarganegaraan ganda setelah Undang-undang Nomor 12 Tahun 2006 tentang Kewarganegaraan disahkan oleh Pemerintah. Penelitian ini bertujuan untuk mengukur sejauh mana anak yang dilahirkan dari perkawinan tersebut mendapatkan hak waris dengan kedudukan masih di bawah umur. Selain itu bagaimana status hukumnya berdasarkan Undang-undang Nomor 1 Tahun 1974 tentang Perkawinan dan Undang-undang Nomor 5 Tahun 1960 tentang Pertanahan terhadap kedudukan hak waris tanah. Penelitian ini menggunakan metode normatif empiris, yaitu melakukan penggabungan metode penelitian hukum yang tidak hanya memandang hukum sebagai disiplin ilmu yang bersifat preskriftif (menentukan) dan terapan, namun sekaligus bersifat deskriptif (memaparkan) yang didasarkan pada kenyataan perkembangan hukum di masyarakat. Hasil penelitian ini memberikan petunjuk bahwa anak yang dilahirkan dari perkawinan antar negara yang berkewarganegaraan ganda dan masih di
\end{abstract}


bawah umur berhak atas hak waris tanah berupa hak milik dengan ketentuan anak tersebut harus memilih kewarganegaraan Indonesia pada saat usianya 18 (delapan belas) tahun berdasarkan peraturan perundang-undangan yang berlaku.

Kata kunci: pewarisan; perkawinan antar negara; kewarganegaraan ganda.

\section{Pendahuluan}

Perkembangan teknologi menjadi salah satu pengaruh globalisasi yang terjadi saat ini termasuk di dalamnya Indonesia. Di mana kecanggihan alat komunikasi dalam interaksi manusia dapat menghubungkan siapa saja dengan mudah, cepat dan efisien, baik antara Warga Negara Indonesia (WNI) maupun Warga Negara Asing (WNA), sehingga turut andil terjadinya fenomena perkawinan antar negara.

Pasal 57 Undang-undang Nomor 1 Tahun 1974 tentang Perkawinan memberikan gambaran bahwa perkawinan tidak hanya bagi pasangan yang memiliki kewarganegaraan sama melainkan bisa juga pada pasangan yang memiliki kewarganegaraan berbeda. Dengan ketentuan perkawinan tersebuh masih didasarkan pada keyakinan yang sama, sedangkan perkawinan antar negara dengan keyakinan berbeda undang-undang ini tidak memberikan celah legalitas. Sehingga untuk keabsahan perkawinannya dapat dilangsungkan di luar negeri di mana ketentuan hukumnya didasarkan pada aturan hukum di negara salah satu pasangan yang kemudian dapat didaftarkan melalui kantor pencatatan sipil setempat.

Perkawinan beda negara berpotensi akan mempengaruhi terhadap kewarganegaraan Indonesia dan status anak yang lahir atas perkawinan tersebut. Salah satu yang harus dicermati bagi pasangan yang akan melangsungkan perkawinan di luar negeri sebagaimana pada Pasal 26 Ayat 1 Undang-undang Nomor 12 tahun 2006 tentang Kewarganegaraan berbunyi:

"Perempuan Warga Negara Indonesia yang kawin dengan laki-laki Warga Negara Asing kehilangan Kewarganegaraan Republik Indonesia jika menurut hukum negara asal suaminya, kewarganegaraan istri mengikuti kewarganegaraan suami sebagai akibat perkawinan tersebut”

Pasal 26 Ayat 2:

"Laki-laki Warga Negara Indonesia yang kawin dengan Perempuan Warga Negara Asing kehilangan Kewarganegaraan Republik Indonesia jika menurut hukum negara asal istrinya, kewarganegaraan suami mengikuti kewarganegaraan istri sebagai akibat perkawinan tersebut".

Adapun bagi yang tetap ingin menjadi Warga Negara Indonesia dapat mengajukan permohonan ke perwakilan Republik Indonesia di wilayah setempat kecuali dalam pengajuannya tersebut mengakibatkannya memiliki kewarganegaraan ganda seperti ketentuan dalam pasal 26 ayat 3 . 
"Status kewarganegaraan yang dimiliki oleh seseorang di Indonesia tidak hanya didasarkan atas garis keturunan saja, namun juga didasarkan atas negara tempat kelahiran, asas kewarganegaraan tunggal serta kewarganegaraan ganda terbatas bagi anak-anak di bawah usia 18 (delapan belas) tahun yang kemudian diharuskan memilih salah satu kewarganegaraan sesuai peraturan perundangan yang berlaku".

Hadirnya Undang-Undang Nomor 12 tahun 2006 sebagai pengganti Undang-undang No. 62 tahun 1958 tentang Kewarganegaraan tidak serta merta menghapuskan segala permasalahan dalam perkawinan antara pasangan beda kewarganegaraan tersebut, termasuk tentang kewarganegaraan ganda yang dimiliki anak di bawah umur. Ada beberapa kendala yang menyebabkan anak tersebut masih berkewarganegaraan ganda dan belum bisa menjadi warga negara Indonesia yaitu persyaratan administrasi yang belum terpenuhi dan adanya konflik dari negara salah satu orang tua.

Sebagai catatan, tercatat hampir 200 (dua ratus) anak di Beijing yang masih berkewarganegaraan ganda dari perkawinan antar negara Indonesia-China. Sebagaimana aturan yang diterapkan, baik Indonesia maupun China sama-sama menganut kewarganegaraan tunggal. Sehingga setelah usia 18 (delapan tahun) diharuskan untuk memilih salah satu kewarganegaraan. Selain itu, perkawinan memberi dampak hukum pada pemilikan yang ditentukan bentuk harta benda rumah tangga, apakah perkawinan itu berakhir (oleh perceraian atau kematian) dan apa akibatnya dalam hubungan-hubungan antara rumah tangga dengan pihak lain? Apabila dalam perkawinan antar negara pasangan yang berkewarganegaraan Indonesia (WNI) meninggal terlebih dahulu dengan meninggalkan ahli waris warga negara asing dan anak di bawah umur maka pewarisannya akan menyisakan persoalan tersendiri karena akan berhadapan dengan kewarganegaraan ganda sebelum usianya 18 (delapan belas) tahun.

Peneliti berharap melalui tulisan ini masyarakat dapat memahami aturan pokok yang telah ditetapkan oleh Pemerintah melalui Undang-undang Nomor 12 Tahun 2006 tentang Kewarganegaraan bagi pasangan yang melakukan perkawinan antar negara dan dilangsungkan di luar negeri, sehingga ketika dikemudian hari terjadi persoalan mengenai hak-hak atas pewarisan suatu benda yang ditinggalkan bagi anak di bawah umur, maka aturan lainnya baik Undangundang Nomor 1 Tahun 1974 tentang Perkawinan maupun Undang-undang Nomor 5 Tahun 1960 tentang Pertanahan menjadi solusi dalam penyelesaian pewarisannya.

Beberapa catatan penting mengenai persoalan ini sebelumnya telah disampaikan oleh penelitian yang dilakukan oleh Andi Syahputra ${ }^{1}$ berkaitan dengan perlindungan anak dalam perkawinan campuran yang bercerai. Selanjutnya penelitian tentang warisan anak dalam perkawinan campuran tanpa wasiat yang

1 Andi Syahputra, Aries Harianto, and Jayus Jayus, "Hak Konstitusional Anak Hasil Perkawinan Campuran Di Indonesia,” Jurnal Ilmiah Ilmu Hukum Faimess and Justice 16, no. 1 (2018): 16-31. 
dibahas oleh Dian Andra ${ }^{2}$ menitikberatkan bahwa perkawinan campuran berpeluang menjadi sebuah persoalan tersendiri bila tanpa ditunjang dengan pemahaman hukum yang sebenarnya.

Berdasarkan fakta tersebut, peneliti berasumsi bahwa anak yang dilahirkan dari perkawinan antar negara dengan kewarganegaraan ganda dan masih di bawah umur berhak atas hak waris tanah berupa hak milik dengan ketentuan anak tersebut harus memilih kewarganegaraan Indonesia pada saat usianya 18 (delapan belas) tahun berdasarkan peraturan perundang-undangan yang berlaku.

\section{Metodologi}

Penelitian ini dilakukan dengan menggabungkan dua penelitian hukum, yaitu penelitian hukum normative (doctrinal legal research) dengan penelitian hukum empiris (empirical legal research). Peneliti tidak hanya melihat hukum hanya dalam ruang lingkup disiplin saja, tetapi memandang hukum pada aspek normative, seperti berkaitan dengan asas-asas hukum, sistematika hukum, sinkronisasi hukum, perbandingan hukum dan sejarah hukum. ${ }^{3}$ Selain itu, peneliti juga melihat pada aspek kenyataan perkembangan hukum di masayarakat (socio empirical legal research) yang bersifat deskriptif pada aspek implementasi atau operasionalisasinya ${ }^{4}$. Hal ini dimaksudkan untuk menilai dan menganalisis tingkat relevansi fakta dan cita-cita hukum di masyarakat, dalam hal ini adalah kepastian terhadap kewarisan hak atas tanah dalam perkawinan antar negara.

\section{Hasil dan Pembahasan}

\section{Perkawinan Antar Negara Beserta Akibat Hukumnya}

Perkawinan bukan hanya menyatukan dua manusia, tetapi menjadi salah satu peristiwa sakral. Faktor agama masih memegang peranan penting dalam kelangsungan suatu perkawinan di Indonesia, karena itu terdapat beberapa persyaratan sebagai keabsahan perkawinan. Berbeda halnya dengan aturan yang tertulis dalam Kitab Undang-undang Hukum Perdata, di mana Hukum Pedata hanya memandang perkawinan dari sudut perdata, sedangkan agama memandang perkawinan dari berbagai hal lainnya. Pasal 26 KUHPerdata tidak memberikan pemahaman mendalam terhadap perkawinan, sedangkan Undangundang Nomor 1 Tahun 1974 memberi pemahaman bahwa perkawinan adalah dianggap sah apabila telah memenuhi persyaratan sesuai agama dan keyakinan yang dianut bagi mereka yang ingin melangsungkan perkawinan. ${ }^{5}$ Sehingga

2 Dian Andriani et al., "Pemisahan Harta Perkawinan Campuran Dan Akibat Hukumnya Jika Diwariskan Tanpa Wasiat Pada Anak Berkewarganegaraan Ganda," Jumal Lex Specialis 1, no. 1 (2020): 61-70.

3 Depri Liber Sonata, "Metode Penelitian Hukum Normatif Dan Empiris: Karakteristik Khas Dari Metode Meneliti Hukum," Fiat Justitia Jurnal Ilmu Hukum Volume 8 N (2014): 26.

4 Ibid, h.27

5 Pasal 2 Ayat 1 Undang-Undang Nomor 1 Tahun 1974 Tentang Perkawinan 
dapat diambil kesimpulan bahwa perkawinan berdasarkan Undang-undang Nomor 1 Tahun 1974 lebih menekankan pada aspek agama dan kepercayaan, sedangkan KUHPerdata hanya memandang dari segi keperdataannya saja.

Selaras dengan pesatnya kemajuan ilmu pengetahuan, teknologi, inovasi dan mobilisasi, maka interaksi antara sesama manusia tidak hanya diseputar lingkungan dan negara yang sama namun juga terjadi dalam wilayah negara yang berbeda. Selanjutnya dari interaksi tersebut melahirkan berbagai hubungan, baik pribadi ataupun kelompok. Salah satu hubungan manusiawi adalah ketertarikan seorang laki-laki dan perempuan dalam suatu ikatan perkawinan yang selanjutnya disebut Perkawinan Antar Negara (Perkawinan Campuran).

Sebagaimana dalam Pasal 57 Undang-undang Nomor 1 Tahun 1974 menyebutkan bahwa perkawinan campuran merupakan perkawinan yang terjadi antara dua orang yang berbeda kewarganegaraan di mana salah satunya merupakan warga negara Indonesia. Sedangkan menurut hukum perdata interasional merupakan perkawinan antara orang yang berbeda wilayah hukum dan tunduk pada hukum masing-masing ataupun perkawinan yang terjadi diantara orang yang berbeda kebangsaannya. Dengan hadirnya ketentuan tersebut, dapat disimpulkan bahwa perkawinan yang dilakukan dengan selain warga Indonesia adalah dibenarkan selama memenuhi persayaratan yang telah diatur dalam peraturan perundang-undangan yang berlaku. Adapun elemen-elemen pada perkawinaan campuran yaitu: (1) perkawinan, (2) hukum yang berbeda, (3) perbedaan kewarganegaraan dan (4) salah satu pihak berkewarganegraan Indonesia. Apabila unsur-unsur dalam Pasal 57 telah terpenuhi dan perkawinan telah terjadi, maka akibat hukum dari perkawinan itu adalah halal. Dari unsur halal tersebut maka akan berimplikasi pada persoalan harta kekayaan atau asset yang diperoleh secara bersama-sama selama perkawinan tersebut berlangsung sehingga menjadi harta bersama. Dengan adanya hubungan perkawinan campuran di Indonesia maka dibutuhkan pengaturan hukum yang kuat sebagai payung hukum yang dapat melindungi berbagai peristiwa akibat perkawinan tersebut. Sepanjang perkawinan antara negara dilakukan sesuai dengan hukum yang berlaku di negara tempat dilaksanakannya perkawinan, maka perkawinan itu sah dan dapat dipertanggungjawabkan sesuai hukum sebagaimana diatur dalam pasal 56 ayat 1 Undang-Undang No 1 Tahun 1974 tentang Perkawinan.

Seanny Scholastica dalam penelitiannya menjelaskan bahwa ada beberapa ketentuan persyaratan administratif bagi Warga Negara Indonesia yang melakukan perkawinan di luar wilayah Indonesia antara lain: (1) Pernyataan atau Kuasa dari orang tua atau wali, (2) Surat keterangan dari dari Kepolisian, (3) Pernyataan belum pernah melangsungkan pernikahan, bagi yang telah pernah menikah (Duda atau janda dapat menyertakan surat keterangan belum melangsungkan pernikahan lagi baik secara agama ataupun hukum. Surat ini harus dimaterai dengan 10.000 beserta salinan akta cerai dan harus diperlihatkan dengan aslinya. (4) Surat dari kelurahan, (5) Surat yang dikeluarkan oleh Kepala Desa ataupun pemimpin setempat, yaitu berupa referensi untuk formulir surat (N1), formulir nama orang tua (N2) dan 
formulir keterengan orang tua (N4), (6) Untuk yang beragama Islam dapat memproses di Kantor Urusan Agama, menyerahkan pas photo 4x6, 3x4, dan 2x3 serta salinan KTP, KK orang tua dan foto dengan latar belakang biru. (7) Visa negara yang dikeluarkan oleh kantor Imigrasi, (8) Pasport, (9) Salinan KTP dan KK dan (1) Terjemahan / salinan surat kelahiran. ${ }^{6}$

Bagi pasangan beda negara yang melakukan perkawinan ini harus memahami aturan dan akibat hukum dikemudian hari. Mengingat jumlah kasus perkawinan campuran di Indonesia jumlahnya semakin meningkat. Masalah yang timbul dari perkawinan ini biasanya berpusar pada status kewarganegaraan anak dan kekayaan yang didapat semasa perkawinan karena akan melibatkan hukum yang berbeda antar keduanya.

Berbagai fenomena tentang perkawinan campuran berpengaruh besar atas status kewarganegaraan anak yang dilahirkan. seperti yang dialami oleh Cipta C.C. yang lahir sebelum berlakunya Undang-undang Nomor 12 tahun 2006 di mana anak yang lahir mengikuti kewarganegaraan ayah. Untuk bisa bekerja di Indonesia, Cipta memegang Kartu Izin Tinggal Sementara (KITAS) yang merupakan undangan dari ibunya sebab ia harus mengikuti sang ayah yang berkewarganegaraan Inggris. Sewaktu bersekolah ia menggunakan visa sosial budaya agar tetap bisa menetap di Indonesia. Hal yang tak kalah rumitnya ketika dia membeli tanah dan rumah yang semua diatasnamakan ibu. Masalah lain yang muncul dikemudian hari adalah apabila ibunya meninggal dunia. Sebagaimana menurut Undang-Undang Pokok Agraria Pasal 21 ayat 1 berbunyi: "hanya warga negara Indonesia yang dapat mempunyai hak milik".

Hal lain juga dialami oleh Kevin Joshua Scheunemann yang lahir di Jerman dari pasangan Indonesia Jerman yang secara otomatis mengikuti kewarganegaran Jerman dari sang ayah. Saat duduk dibangku sekolah menengah pertama (SMP) kelas 1 keluarganya pindah ke Indonesia. Namun keluarganya tidak mengetahui adanya status kewarganegaraan ganda terbatas yang dimiliki oleh Kevin karena tidak mengetahui sosialisasi tersebut. Sekembalinya dari Amerika Serikat saat berusia 21 (dua puluh satu) tahun Kevin yang awalnya telah memiliki Kartu Izin Tetap (KITAP) harus mengubah izinnya menjadi Kartu Izin Tinggal Sementara (KITAS). Usahanya terus berlanjut supaya menjadi Warga Negara Indonesia, tahapan berikutnya Kevin harus memiliki kembali KITAP. Walaupun kedua orang tuanya adalah Warga Negara Indonesia, tetapi Kevin harus mengikuti proses naturalisasi dan selama statusnya masih dengan KITAS, Kevin belum mendapat pekerjaan.

Selanjutnya hal lain seputar perkawinan antar negara dapat dilihat dari pasangan artis Melaney Ricardo dan Tyson Lynch. Pasangan Indonesia Australia tersebut masih tetap mempertahankan kewarganegaraan masing-masing.

6 Sheanny Scholastica et.al., "Keabsahan Pencatatan Perkawinan Diluar Indonesia Berdasarkan Peraturan Perundang-Undangan,” Kerta Wicaksana, Sarana Komunikasi Dosen Dan Mahasiswa, 2020, 139-46. 
Dari perkawinan tersebut mereka telah dikarunia 2 (dua) anak yang masih di bawah umur dan memiliki kewarganegaraan ganda hingga masing-masing diantara mereka genap berusia 18 (delapan belas) tahun untuk memilih kewarganegaraan ibu atau ayahnya. Apabila anak-anak tersebut menetap tinggal di Indonesia, maka peraturan yang diberlakukan terhadap keduanya yaitu affidavit. Aturan ini merupakan fasilitas yang diberikan oleh pemerintah Republik Indonesia bagi anak-anak yang memiliki paspor kewarganegaraan ganda terbatas.

Salah satu hal yang paling sensitif dalam perkawinan adalah masalah harta yang dibawa oleh masing-masing pihak ketika akan mengikat dalam sebuah ikatan perkawinan yang sah menurut hukum yang berlaku di Indonesia. Ketika hal tersebut terjadi pihak pria ataupun wanita masing-masing memiliki harta bawaan yang diperoleh dari hasil usaha, pekerjaan dan warisan keluarga masing masing. Maka ketika berumah tangga harta tersebut perlu dijelaskan secara tertulis, karena sistem yang berlaku dalam penanganan harta bawaan calon pasangan suami istri tidak diatur dalam aturan hukum spesifik. Karena itu dibutuhkan kesadaran masing-masing calon pasangan suami istri untuk mengadakan kesepakatan tentang pengakuan harta bawaan tersebut dan cara memperlakukannya ketika sudah terikat dalam sebuah perkawinan yang sah.

Adapun bagi perkawinan yang dilakukan di luar Indonesia, supaya memenuhi legalitasnya dalam hukum perkawinan sebagaimana diatur dalam Pasal 56 Ayat 2 Undang-Undang No 1 tahun 1974 tentang Perkawinan, maka perkawinan tersebut harus segera didaftarkan ke kantor Perkawinan di lingkungan setempat dalam jangka waktu 1 (satu) tahun sekembalinya ke Indonesia. Bagi pasangan yang beragama Islam, dapat mendaftarkan perkawinannya di Kantor Urusan Agama, sedangkan agama selain Islam dapat mendaftarkan perkawinannya di Kantor Catatan Sipil.

Ketentuan ini merupakan sebuah konsekuensi hukum sebagaimana telah diatur dalam Surat Mahkamah Agung Nomor 3 Tahun 2015 tentang Pelaksanaan Perkembangan Hasil Rapat Paripurna MA Tahun 2015 sebagai Pedoman Pelaksanaan Tugas MA bahwa perkawinan dianggap tidak pernah ada apabila perkawinan tersebut dilakukan di luar wilayah negara Indonesia dan tidak didaftarkan di kantor perkawinan setempat, sehingga akibat dari perkawinan tersebut dapat mempengaruhi status hukum anak yang dilahirkan.

Sebelum hadirnya Undang-undang Nomor 12 tahun 2006 tentang Kewarganegaraan, Indonesia masih memberlakukan aturan yang sebelumnya yaitu Undang-undang Nomor 62 tahun 1958. Di mana aturan ini memberikan batasan terhadap hubungan Ibu dan Anak apabila perkawinan tersebut diputus akibat perceraian. Sehingga masyarakat berasumsi bahwa keadilan sulit didapat-

\footnotetext{
7 Bentuk fasilitas keimigrasian yang diberikan pemerintah Indonesia kepada seorang anak pemegang paspor asing yang berkewarganegaraan ganda terbatas sesuai dengan UU No. 12 Tahun 2006 tentang Kewarganegaraan (“UU Kewarganegaraan”), PP No. 2 Tahun 2007, Permenhukham No. M.01-HL.03.01 Tahun 2006
} 
kan akibat perkawinan antar negara yang kemudian hari terjadi perceraian terutama legalitas hubungan kewarganegaraan anak-anak yang hidup bersama. Dari pengalaman tersebut, pemerintah (DPR bersama-sama Presiden) akhirnya melakukan evaluasi dan revisi aturan sebelumnya dengan diundangkannya Undang-undang Nomor 12 tahun 2006 tentang Kewarganegaraan pada tanggal 11 Juli 2006, dengan formulasi hukum mengizinkan pembatasan kewarganegaraan ganda, selain itu juga memberikan pembekalan baru dalam mengatasi isu-isu yang muncul akibat perkawinan antar negara (campuran).

Kewarganegaraan di Indonesia ditentukan oleh 2 (dua) asas, yaitu kelahiran dan perkawinan. Asas kelahiran terdiri dari ius soli dan ius sanguinis. Yang dimaksud dengan ius soli yaitu kewarganegaraan yang dilihat dari negara atau bangsa kelahirannya. Sedangkan yang dimaksud dengan ius sanguinus yaitu kewarganegaraan yang ditentukan dari darah atau keturunnnya. Selanjutnya penentuan kewarganegaran yang ditentukan dari asas perkawinan terdiri dari asas kesatuan hukum dan adanya asas persamaan derajat. Dalam asas kesatuan hukum dapat disimpulkan bahwa suami dan isteri merupakan satu kesatuan yang kuat dalam kehidupan masyarakat. Sedangkan yang dimaksud dengan asas persamaan derajat adalah adanya kesamaan status suami dan isteri tanpa membedakan jenis kelamin atau kedudukan dalam rumah tangga.

Hilman Hadikusuma berpendapat bahwa secara hukum Undang-undang Nomor 12 tahun 2006 tentang Kewarganegaraan memiliki tujuan melindungi status kewarganegaraan wanita Indonesia ketika menikah dengan laki-laki asing, sehingga mereka tetap memiliki kemampuan untuk mempertahankan kewarganegaraan Indonesia dan menjamin legalitas yang kuat bagi anak yang Ibunya WNI dan Ayahnya WNA hingga berusia di bawah 18 (delapan belas) tahun. Selanjutnya anak tersebut dapat menentukan pilihannya untuk memilih salah satu kewarganegaraan dari kedua orang tuanya. ${ }^{8}$

Bayu Sudarmawan menjelaskan sebelum pemerintah mengesahkan Undang-undang Nomor 12 tahun 2006, anak yang lahir kemudian bertempat tinggal di Indonesia hingga berlakunya undang-undang tersebut diberlakukan, maka per 1 Agustus 2010 orang tua ataupun wali berkewajiban mendaftarkan status anak tersebut kepada Kementerian Hak Asasi Manusia dan Pelayanan Hak Asasi Manusia. Apabila, lahir setelah penegakan hukum diberlakukan, maka anak tersebut secara otomatis berstatus kewarganegaraan ganda dan akan diberikan sertifikat imigrasi dengan pasport asing. ${ }^{9}$

8 Joejoen Tjahjani, "Perkawinan Campuran Menurut Undang-Undang Nomor 12 Tahun 2006 Tentang Kewarganegaraan Republik Indonesia" 2 (2006): 22-33, https://doi.org/https://doi.org/10.30736/ji.v1i2.9.

9 I Gede Wardana Oka Sastra Wiguna, I Nyoman Putu Budhiarta, and I Putu Gede Seputra, "Status Kewarganegaraan Anak Hasil Perkawinan Campuran Yang Lahir Pasca Berlakunya Undang-Undang Nomor 12 Tahun 2006 Tentang Kewarganegaraan Republik Indonesia," Jumal Analogi Hukum 1, no. 2 (2020): 88-92. 
Secara hukum perdata Internasional, kewarganegaraan ganda yang dimiliki oleh anak pada perkawinan campuran memiliki persoalan yang cukup serius di mana meyangkut tentang status personal berdasarkan atas asas nasionalitas. Selama hukum nasional dari masing-masing tidak bertentangan, maka tidak akan timbul masalah. Sebaliknya apabila hukum nasional yang dimilikinya bertentangan, maka anak tersebut akan mengalami kesulitan atas hukum nasional yang harus diikutinya. Adanya hubungan hukum yang dilakukan antara orangorang secara pribadi menimbulkan berbagai macam hak dan komitmen baru bagi individu tersebut dan negaranya. Hubungan campuran yang dilakukan antara subjek dengan berbagai kepatuhan yang sah dapat menyebabkan masalah baru, khususnya tergantung pada hukum mana individu tersebut, dan hukum mana yang berlaku dalam menangani masalah dan situasi dengan kekuatan individu tergantung di mana ia tinggal. Kewarganegaraan dapat menjadi bagian dari partisipasi dari suatu kolektivitas orang-orang. Di mana aktivitas, pilihan dan pendekatan mereka dirasakan melalui gagasan hukum negara yang menangani orang-orang ini.

Yoga Sahari berpendapat bahwa warga negara yang menjadi anggota suatu negara memiliki tanggung jawab dan hubungan dengan negara. Mereka yang telah disetujui oleh pemerintah harus ditentukan menurut kesepakatan yang dibuat di negara itu. Aturan-aturan ini berfungsi sebagai prinsip atau aturan untuk menentukan kewarganegaraan seseorang. Setiap negara memiliki fleksibilitas dan kontrol untuk memutuskan kewarganegaraan individunya. ${ }^{10}$

Suciati menuliskan tentang tatacara mendaftarkan anak yang memiliki kewarganegaraan ganda berdasarkan Undang-undang Nomor 12 tahun 2006 sebagai berikut: (1) Anak-anak dengan kewarganegaraan ganda harus didaftarkan oleh orang tua atau walinya apabila dilakukan di luar negara Indonesia maka ditujukan kantor imigrasi setempat yang meiliputi domisili anak; (2) Memenuhi syarat yang ditentukan; (3) Melampirkan formulir pendaftaran dengan dokumen terlampir; (4) Pendaftaran diverifikasi, jika pernyataan itu sah dan benar, petugas penerima mendaftarkannya dan mencatatnya dalam buku anak kewarganegaraan ganda; (5) Paspor yang diterbitkan biasa dan tercatat sebagai anak berkebangsaan ganda serta surat pernyataan mendapatkan. ${ }^{11}$

Sebagaimana dalam lingkup hukum keluarga, terdapat 2 (dua) status anak dalam hukum perkawinan, yaitu anak sah dan anak luar kawin. Pasal 42 Undang-undang Perkawinan menjelaskan tentang maksud dari anak sah yaitu anak yang lahir dalam pernikahan yang telah memenuhi persyaratan dalam hukum Islam. Sedangkan ketentuan tentang anak luar kawin ditetapkan dalam Pasal 43, yaitu anak yang hanya punya ikatan perdata dengan ibu dan keluarga-

10 Yoga Sahari, "Hak-Hak Atas Tanah Dalam Sistem Hukum Pertanahan Di Indonesia Menurut Undang-Undang Pokok Agraria (UUPA)," Jurnal Mitra Manajemen 9, no. 1 (2017): 15-23.

11 Hanan, Suciati, and Anindya Bidasari, "Status Dan Kedudukan Anak Dari Perkawinan Campuran Menurut Undang-Undang Nomor 12 Tahun 2006," Nomos:Jumal Penelitian Ilmu Hukum 1, no. 1 (2021): 20-25. 
nya. Hukum Islam mengatur tentang kedudukan anak sebagaimana ketentuannya diatur dalam Kompilasi Hukum Islam Pasal 99 dan 100.

Pasal 99 KHI yang dimaksud dengan anak sah yaitu : “(a) anak yang dilahirkan dalam atau akibat perkawinan yang sah dan (b) hasil perbuatan suami isteri yang sah diluar rahim dan dilahirkan oleh isteri tersebut". Adapun Pasal 100 mengatur bahwa anak-anak yang tidak sah hanya berhubungan dengan ibu dan keluarganya".

\section{Pewarisan Hak Atas Tanah Bagi Anak}

Pasal 57 Undang-undang Nomor 1 Tahun 1974 tentang Perkawinan memberikan penjelasan bagi perkawinan antar negara, di mana dua orang dari kebangsaan yang berbeda diberikan izin untuk melakukan perkawinan karena salah satunya adalah berkebangsaan Indonesia. Dari penjelasan tersebut, perkawinan akan berimplikasi terhadap ketentuan harta bersama berdasarkan hukum perkawinan.

Lebih lanjut, KUHPerdata memberikan penjelasan kembali tentang harta bersama, sebagaimana uraian Pasal 119 bahwa ketika perkawinan dilaksanakan akan ada penggabungan antara harta kedua belah pihak kecuali dibuat perjanjian perkawinan diantara keduanya maupun adanya perubahan sepanjang persetujuan antara keduanya. Persekutuan harta selama masa perkawinan tidak dapat dibatalkan atau diubah dengan persetujuan suami istri dengan cara apapun. Jika mereka bermaksud melanggar ketentuan ini, suami dan istri harus mengikuti jalur perkawinan yang ditentukan oleh pasal 139 sampai $154 \mathrm{KUH}$ Perdata.

Perjanjian perkawinan mungkin tidak terlalu berpengaruh dalam perkawinan antar sesama warga negara Indonesia. Namun keadaan ini tentu berbeda dalam perkawinan yang melibatkan dua kewarganegaraan yang berbeda terutama dalam hal kepemilikan tanah. Apabila perjanjian perkawinan tidak dilakukan dalam perkawinan tersebut, maka akan dianggap sebagai harta bersama dalam perkawinan. Sehingga warga negara Indonesia akan kehilangan haknya atas tanah dengan status hak milik tersebut. Hal yang harus dicermati bagi pasangan yang berbeda kewarganegaraan dan melakukan perkawinan campuran, maka perihal kepemilikan benda tak bergerak (tanah dan bangunan) dan benda bergerak (kendaraan bermotor, perhiasan dan benda lainnya) dalam hal tidak dilakukan perjanjian dalam perkawinan campuran sehingga salah satu diantaranya meninggal tanpa meninggalkan surat wasiat, maka salah satu pasangan yang masih hidup (suami atau istri) berkewarganegaraan asing beserta keturunannya berlaku ketentuan hak milik bersama untuk dibagikan secara rata dalam proses pewarisannya. Ketentuan pokok ini diatur dalam Pasal 35 Ayat (1) dan (2) yaitu: bahwa kekayaan yang dihasilkan selama perkawinan menjadi milik bersama; dan bahwa warisan atau pemberian merupakan kekayaan yang diperoleh dan dimiliki masing-masing pasangan terkecuali ada ada sebab lain. 
Sebagaimana penjelasan yang dipaparkan oleh Andriani mengenai permasalahan di atas, tentunya akan berhadapan dengan asas nasionalitas Indonesia perihal kepemilikan tanah. Di mana Pasal 9 Undang-undang Pokok Agraria menyebutkan bahwa hanya bangsa Indonesia yang bisa memiliki secara utuh bumi, air dan ruang angkasa seperti yang tertera pada Pasal 1 ayat (1) dan (2) ${ }^{12}$. Karena itu pasangan Warga Negara Indonesia dan Warga Negara Asing yang telah melakukan perkawinan campuran dan memiliki anak, maka ada aturan tambahan yang perlu dicermati mengenai pembagian warisnya yaitu pengaturan dari susunan yang berhubungan dengan kekayaan benda ditetapkan oleh hukum suami. Jika tidak ada perjanjian perkawinan, maka kekayaan perkawinan campuran ini dikenai Pasal 35 Ayat 1 Undang-undang Nomor 1 Tahun 1974, di mana Ayat 1 menjelaskan bahwa kekayaan yang diperoleh selama perkawinan menjadi milik bersama, sedangkan Pasal 2 menjelaskan bahwa harta bawaan masing-masing pasangan dan harta yang diperoleh setiap orang sebagai kekayaan masing-masing pasangan hidup dan harta yang diperoleh masingmasing individu sebagai pemberian atau warisan, berada di bawah kendali masing-masing individu selama tidak dikecualikan hal lain. Saat ini aturan Hukum Islam, Perdata dan Adat masih dijadikan patokan dalam persoalan waris terhadap perkawinan campuran, mengingat Indonesia belum mengatur secara khusus ketentuan hukum mengenai persoalan tersebut.

Perceraian dan kematian menjadi salah satu akibat berakhirnya sebuah perkawinan. Dari hal tersebut tentunya ada yang meninggalkan harta (warisan) atau sebaliknya. Bagi Muslim pembagian harta diatur berdasarkan al-Quran dan Kompilasi Hukum Islam (KHI), sedangkan non-Muslim diatur berdasarkan KUHPerdata. Pembagian waris berdasarkan KUHPerdata pada prinsipnya memberlakukan semua ahli waris, baik laki-laki maupun perempuan berkewarganegaraan Indonesia atau Asing berhak atas pembagian waris yang sama.

Pasal 830 KUHPerdata mengatur bahwa terbukanya warisan apabila terjadinya kematian. Selain itu, Pasal 832 KUHPerdata menyebutkan adanya pertalian darah antara ahli waris dan ahli waris, kecuali dalam hal suami atau istri dari ahli waris masih terikat secara hukum dalam perkawinan pada saat ahli waris menikah. Hukum waris yang diatur dalam KUHPerdata merupakan seperangkat aturan yang mengatur tentang kekayaan orang yang meninggal, yaitu pemindahan harta yang ditinggalkan dengan pewaris dan berpindah kepada ahli waris maupun yang ada hubungan pertalian darah dengannya. ${ }^{13}$

Pasal 171 angka (1) Kompilasi Hukum Islam menyebutkan Hukum waris adalah hukum yang mengatur tentang pemindahan kepemilikan harta warisan (tirkah) oleh ahli waris, siapa yang mempunyai hak menjadi ahli waris dan

12 Andriani et al., "Pemisahan Harta Perkawinan Campuran Dan Akibat Hukumnya Jika Diwariskan Tanpa Wasiat Pada Anak Berkewarganegaraan Ganda."

13 Indah Sari and M Si, "Pembagian Hak Waris Kepada Ahli Waris Ab Intestato Dan Testamentair Menurut Hukum Perdata Barat (BW)," Jurnal Ilmiah Hukum Dirgantara 5, no. 1 (2014): 1-20, https://doi.org/10.35968/jh.v5i1.99. 
berapa banyak masing-masing yang menjadi hak ahli waris. Pasal 171 angka (3) mengatur bahwa ahli waris adalah orang yang pada saat kematian, memiliki korelasi darah atau perkawinan dengan ahli waris, seorang muslim dan tidak dilarang oleh hukum untuk menjadi ahli waris. Seorang ahli waris dianggap muslim dapat dilihat dari kartu tanda pengenal atau dari pengakuan, sedangkan untuk anak di bawah umur didasarkan dari agama ayah atau latar belakangnya seperti yang tercantum dalam pasal $172 \mathrm{KHI}$.

Persoalan yang ditimbulkan dari perkawinan antar negara (campuran) adalah saat warga negara Indonesia tersebut meninggal dan meninggalkan warisan pada penerima waris yang bukan berkewarganegaraan Indonesia serta anak yang masih di bawah umur dalam bentuk harta peninggalan berupa benda tidak bergerak (tanah dan/atau bangunan). Sehingga salah satu alternatif untuk meminimalisir konflik dan perselisihan dapat dilakukan dengan melakukan perjanjian pra-kawin/pra-nikah. Hal ini dapat dipraktikkan oleh pasangan berbeda kewarganegaraan ketika akan melakukan perkawinan campuran sebagai salah satu solusi bila dikemudian hari terjadi perceraian dan/atau salah satu pasangan meninggal dunia.

Perjanjian pra-nikah merupakan dokumen tertulis yang menjadi pokok kesepakatan calon pasangan sebelum dilangsungkan perkawinan yang secara garis besar di dalamnya memuat perihal pengakuan harta yang dibawa oleh masing-masing pasangan, klasifikasi harta yang akan dimasukkan ke dalam harta bersama dan/atau harta bawaan yang akan disepakati menjadi harta bersama ketika perkawinan telah terjadi. Selain itu, perjanjian pra-nikah dapat menuangkan kesepatan tertulis tentang harta bersama yang akan diakui sebagai harta masing-masing, sehingga bentuk perjanjian pra-nikah ini akan sangat fleksibel sesuai dengan keperluan dari pihak-pihak yang bersepakat untuk menuangkan secara terperinci. Bila perjanjian pra-nikah tidak dilakukan sebelum perkawinan, maka dapat dilakukan pasca nikah yang secara pokok melindungi harta yang dibawa masing-maisng pihak sebelum perkawinan. Selanjutnya sumber dan klasifikasi harta yang diakui oleh masing-masing pasangan dituangkan dalam suatu perjanjian yang mengikat sebagai harta bersama dan yang bukan termasuk harta bersama, sehingga harta tersebut dapat dengan jelas dikategorikan untuk diwariskan kepada pasangan suami atau istri dan anak keterunan atau dapat juga dihibahkan kepada pihak di luar garis waris.

Anak merupakan keturunan yang menjadi penerus bagi keluarganya kelak sehingga selayaknya ia memperoleh apa yang seharusnya ia peroleh termasuk warisan dari orang tuanya (pewaris). Bagi anak-anak yang lahir dari ikatan hubungan perkawinan campuran, mempunyai ayah dan ibu dari berbagai kebangsaan dan selanjutnya tunduk pada dua lingkungan sah yang berbeda. Perkawinan WNI dengan WNA akan mengubah kedudukan kepemilikan tanah menjadi kepemilikan bersama dalam perkawinan campuran, terkecuali dalam hal pasangan tersebut membuat perjanjian perkawinan sehingga tanah tersebut tetap menjadi hak milik pasangan yang berkewarganegaraan Indonesia. 
Pasal 6 UUPA menjelaskan bahwa hak milik merupakan hak waris yang paling lengkap dan permanen di muka bumi sehingga sifat hak milik mempunyai perbedaan dengan hak-hak lainnya. Hak milik adalah hak waris, yang merupakan hak yang paling kuat dan menyeluruh yang dapat dimiliki oleh setiap orang di muka bumi. Dari empat hak atas tanahnya yang disebutkan, hanya warga negara Indonesia (WNI) saja yang dapat mempunyai tanah hak milik di Indonesia. Sesuai ketentuan tersebut, Pasal 21 Ayat (3) menjelaskan bahwa orang asing yang bukan berkewarganegaraan Indonesia wajib melepaskan hak milik tanah yang diperoleh dari warisan tanpa wasiat dalam jangka waktu (1) satu tahun sebelum tanah tersebut akan jatuh kepada negara.

Pemberlakukan aturan baku tentang batas kepemilikan tanah oleh warga negara Indonesia memperjelas bahwa tujuan utama pembuat undang-undang adalah untuk memberikan jaminan yang lebih penting dan memberikan perlindungan atas pemiilikan tanah yang dimiliki oleh WNI sebagaimana dalam pasal 21 ayat 1 UUPA. Pengaturan ketentuan yang menyebabkan perlakuan tersebut sebenarnya masih dalam batas kewajaran, khususnya mengenai pembahasan tentang pertanahan, yang dianggap sebagai landasan dasar berdirinya suatu bangsa atau rakyat di atas wilayah atau kedaulatannya. ${ }^{14}$ Tanah tidak hanya milik sebagian orang saja, melainkan milik seluruh rakyat di Indonesia. Di mana tanah harus mendahulukan kebutuhan orang banyak dibandingkan kebutuhan sendiri atau golongan. ${ }^{15}$

Pasal 4 ayat (1) UUPA menyimpulkan Negara menguasai apa yang terkandung di dalam dan di atas bumi dan dapat diberikan hak di atasnya kepada warga negara baik dalam kepemilikan atau sewa. Waris menjadi hal yang sensitif bila dalam praktiknya masih menyisakan persoalan. Karena itu, perlu dipahami bahwa Indonesia telah mengatur pembagian waris berdasarkan Hukum Islam, Hukum Adat dan Hukum Perdata. Adapun pembagian waris yang didasarkan atas perkawinan campuran, saat ini belum ada aturan tersendiri, melainkan masih mengacu pada aturan yang termuat dalam Undang-undang Kewarganegaraan, Undang-undang Perkawinan, dan KUHPerdata. Pasal 35 Ayat 1 memberikan gambaran bahwa pasca perkawinan yang ada hanya harta bersama, sedangkan harta yang dimiliki sebelum perkawinan tetap menjadi harta masingmasing sehingga diadakan perjanjian yang disepakati oleh keduanya.

Penjelasan lain mengenai harta, diperjelas kembali dalam Pasal 21 Ayat (3) dan (4) UUPA di mana orang yang bukan warga negara Indonesia dan/atau yang kehilangan status kewarganegaraannya maka secara hukum akan kehilangan hak-hak kewarisannya berikut fasilitas lainnya yang telah diberikan oleh

14 I Putu Gede Bayu Sudarmawan, I Gusti Bagus Suryawan, and Luh Putu Suryani, "Kepemilikan Hak Atas Tanah Dalam Perkawinan Campuran,” Jumal Konstruksi Hukum 1, no. 1 (2020): 153-63.

15 Indah Sari, "Hak-Hak Atas Tanah Dalam Sistem Hukum Pertanahan Di Indonesia Menurut Undang-Undang Pokok Agraria (UUPA)," Jumal Mitra Manajemen 9, no. 1 (2017): 15-33. 
negara dalam tempo waktu 1 (satu) tahun setelah status tersebut dicabut dan secara otomatis kepemilikannya akan kembali kepada negara. ${ }^{16}$

Selanjutnya bila suami atau istri dengan kewarganegaraan Indonesia meninggal dunia dan meninggalkan benda kepemilikan berupa tanah maka untuk mengantisipasi persoalan yang ditimbulkan terhadap pewarisan hak atas tanah perlu dilakukan beberapa hal, diantaranya: (1) melaksanakan wasiat sesuai dengan peraturan perundang-undangan mengenai hak-hak milik ahli waris; (2) tidak ada ketentuan hukum pemindahan hak terhadap kewarganegaraan ganda dapat diberikan dengan status hak milik sebelum menjadi Warga Negara Indonesia pada saat berusia 18 (delapan belas) tahun. Berdasarkan Pasal 21 Ayat (3) UUPA menjelaskan bahwa pasangan yang masih berstatus warga negara Asing wajib melepaskan dan mengalihkan haknya kepada pihak lain dalam tempo waktu 1 (satu) tahun sejak pewaris meninggal dunia, dengan ketentuan bila hak tersebut tidak dialih pindahkan secara otomatis menjadi milik negara.

Begitu pula dengan status anak berkewarganegaraan ganda, sebelum anak tersebut genap berusia 18 (delapan belas) tahun status kepemilikan benda yang ditinggalkan oleh orang tuanya akibat perceraian atau kematian hanya sebatas Hak Pakai (HP), sedangkan setelah usianya 18 (delapan belas) tahun atau telah menikah supaya tidak kehilangan haknya maka diharuskan memilih Kewarganegaraan Indonesia dengan ketentuan sebelum peralihan tersebut harus melakukan naturalisasi untuk mendapatkan status Warga Negara Indonesia berdasarkan peraturan perundang-undangan yang berlaku, sehingga pewarisan hak atas tanah dapat dimiliki dengan status Hak Milik.

\section{Kesimpulan}

Hadirnya Undang-Undang Nomor 12 tahun 2006 sebagai pengganti Undang-undang Nomor 62 tahun 1958 tentang Kewarganegaraan tidak serta merta menghapuskan segala persoalan dalam perkawinan antara pasangan beda kewarganegaraan, termasuk tentang kewarganegaraan ganda yang dimiliki anak di bawah umur. Secara hukum perdata Internasional, kewarganegaraan ganda yang dimiliki oleh anak pada perkawinan campuran memiliki persoalan yang cukup serius meyangkut status personal berdasarkan atas asas nasionalitas. Selama hukum nasional dari masing-masing tidak bertentangan, maka tidak akan timbul masalah. Sebaliknya apabila hukum nasional yang dimilikinya bertentangan, maka anak tersebut akan mengalami kesulitan atas hukum nasional yang harus diikutinya. Waris menjadi hal yang sensitif bila dalam praktiknya masih menyisakan persoalan. Karena itu, perlu dipahami bahwa Indonesia telah mengatur pembagian waris berdasarkan Hukum Islam, Hukum Adat dan Hukum Perdata. Sebagai catatan anak yang dilahirkan dari perkawinan beda

16 Irma Bandiyah and Abraham Ferry Rosando, "Kepemilikan Hak Atas Tanah Warga Negara Indonesia Yang Melaksanakan Perkawinan Campuran,” DiH Jurnal Ilmu Hukum 13, no. 25 (2017): 105-23. 
negara dengan status kewarganegaraan ganda ketika berakhirnya perkawinan orang tuanya diakibatkan perceraian dan/atau kematian, maka status kepemilikan benda yang ditinggalkan hanya sebatas Hak Pakai, sedangkan setelah usianya 18 (delapan belas) tahun atau telah menikah supaya tidak kehilangan haknya maka diharuskan memilih Kewarganegaraan Indonesia dengan ketentuan sebelum peralihan tersebut melakukan naturalisasi untuk mendapatkan status WNI berdasarkan peraturan perundang-undangan yang berlaku, sehingga pewarisan hak atas tanah dapat dimiliki dengan status Hak Milik.

\section{Daftar Pustaka}

Andriani, Dian, Santoso, Bambang, and Oksidelfa Yanto. "Pemisahan Harta Perkawinan Campuran Dan Akibat Hukumnya Jika Diwariskan Tanpa Wasiat Pada Anak Berkewarganegaraan Ganda.” Jurnal Lex Specialis 1, no. 1 (2020): 61-70.

Bandiyah, Irma, and Abraham Ferry Rosando. "Kepemilikan Hak Atas Tanah Warga Negara Indonesia Yang Melaksanakan Perkawinan Campuran." DiH Jurnal Imu Hukum 13, no. 25 (2017): 105-23.

Hanan, Suciati, and Anindya Bidasari. "Status Dan Kedudukan Anak Dari Perkawinan Campuran Menurut Undang-Undang Nomor 12 Tahun 2006." Nomos:Jurnal Penelitian Ilmu Hukum 1, no. 1 (2021): 20-25.

I Gede Wardana Oka Sastra Wiguna, I Nyoman Putu Budhiarta, and I Putu Gede Seputra. "Status Kewarganegaraan Anak Hasil Perkawinan Campuran Yang Lahir Pasca Berlakunya Undang-Undang Nomor 12 Tahun 2006 Tentang Kewarganegaraan Republik Indonesia." Jurnal Analogi Hukum 1, no. 2 (2020): 88-92.

Sahari, Yoga. "Hak-Hak Atas Tanah Dalam Sistem Hukum Pertanahan Di Indonesia Menurut Undang-Undang Pokok Agraria (UUPA)." Jurnal Mitra Manajemen 9, no. 1 (2017): 15-23.

Sari, Indah. "Hak-Hak Atas Tanah Dalam Sistem Hukum Pertanahan Di Indonesia Menurut Undang-Undang Pokok Agraria (UUPA)." Jurnal Mitra Manajemen 9, no. 1 (2017): 15-33.

Sari, Indah, and M Si. "Pembagian Hak Waris Kepada Ahli Waris Ab Intestato Dan Testamentair Menurut Hukum Perdata Barat (BW)." Jurnal Ilmiah Hukum Dirgantara 5, no. 1 (2014): 1-20. https://doi.org/10.35968/jh.v5i1.99.

Sheanny Scholastica, Gavrilla Theodora, Olga Nadina, and Tsamara Probo Ningrum. "Keabsahan Pencatatan Perkawinan Diluar Indonesia Berdasarkan Peraturan Perundang-Undangan." Kerta Wicaksana, Sarana Komunikasi Dosen Dan Mahasiswa, 2020, 139-46.

Sonata, Depri Liber. "Metode Penelitian Hukum Normatif Dan Empiris: 
Karakteristik Khas Dari Metode Meneliti Hukum.” Fiat Justitia Jurnal Ilmu Hukum Volume 8 N (2014): 26.

Sudarmawan, I Putu Gede Bayu, I Gusti Bagus Suryawan, and Luh Putu Suryani. "Kepemilikan Hak Atas Tanah Dalam Perkawinan Campuran." Jurnal Konstruksi Hukum 1, no. 1 (2020): 153-63.

Syahputra, Andi, Aries Harianto, and Jayus Jayus. "Hak Konstitusional Anak Hasil Perkawinan Campuran Di Indonesia." Jurnal Imiah Ilmu Hukum Fairness and Justice 16, no. 1 (2018): 16-31.

Tjahjani, Joejoen. "Perkawinan Campuran Menurut Undang-Undang Nomor 12 Tahun 2006 Tentang Kewarganegaraan Republik Indonesia" 2 (2006): 22 33. https://doi.org/https://doi.org/10.30736/ji.v1i2.9. (CC BY SA) license (https://creativecommons.org/licenses/by-sa/3.0/). 